\title{
RESISTÊNCIA DE AEDES AEGYPTI AO INSETICIDA TEMEFOS
}

João Paulo Pereira ROSA*

* Mestre, Coordenador e Docente do Curso de Farmácia da UninCor. coord.farmacia@unincor.edu.br

Recebido em: 08/10/2015 - Aprovado em: 17/04/2016 - Disponibilizado em: 30/07/2016

\begin{abstract}
RESUMO
Este trabalho teve como objetivo contribuir brevemente para a discussão sobre genes envolvidos na resistência ao temefos em populações de Aedes aegypti, por meio da revisão de artigos publicados sobre o tema. A partir de uma consulta à base de dados Pubmed, utilizando termos descritores relacionados, verificou-se a incidência de estudos. Após isso, foi feita a identificação dos artigos que se referiam diretamente à questão de interesse, buscando despertar para a necessidade de se investigar de forma mais aprofundada e sistemática.
\end{abstract}

Palavras-chave: Aedes aegypti. Resistência. Inseticida.

\section{Strength of the Aedes aegypti insecticide temephos}

\begin{abstract}
This study aimed to contribute briefly to the discussion of genes involved in resistance to temephos in Aedes aegypti populations, through the review of articles published on the topic. The query from a PubMed database, using terms related descriptors, we found the incidence studies. After this, the identification was made of articles that referred directly to the question of interest, seeking to awaken to the need to investigate more thoroughly and systematically.

Keywords: Aedes aegypti. Resistance. Insecticide.
\end{abstract}

\section{INTRODUÇÃO}

A dengue é considerada a principal doença viral que anualmente afeta milhares de seres humanos. O controle do mosquito Aedes aegypti envolve a utilização de inseticidas, dentre os quais se destaca o temefos.

Entretanto, devido ao seu uso intenso, o vetor de tem demonstrado resistência ao inseticida (RICARDO et al, 2010). Pensando nisso, é importante compreender os mecanismos de resistência, a fim de contribuir para o progresso de métodos capazes de supera-los (POUPARDIN et al, 2014).
Em outras palavras, a compreensão de mecanismos de resistência relacionados ao Aedes aegypti faz parte de uma importante área de pesquisa enfocada na minimização da evolução do quadro de infecções e consequente redução do impacto de resistência aos seres humanos.

Para tanto, o monitoramento do processo de evolução é realizado com base na pesquisa de alelos mutantes que desencadeiam a resistência (CHEN et al, 2013).

Diferentes mecanismos induzem o mosquito Aedes aegypti à resistência. Dentre 
eles, destaca-se alterações do sítio-alvo e a via metabólica. O processo metabólico é representado por enzimas de detoxificação, como esterases, glutationas S-tranferases e oxidases. Todavia, mais de 200 genes de detoxificação foram identificados em Aedes. aegypti, o que torna complexa e difícil a identificação de mutações pontuais envolvidas no mecanismo de resistência (STRODE et al, 2012).

Este fato se dá como um problema de pesquisa válido à ser discutido. Justifica-se, portanto, o desenvolvimento deste artigo.

\section{OBJETIVO}

Contribuir brevemente para a discussão sobre genes envolvidos na resistência ao temefos em populações de Aedes aegypti.

\section{METODOLOGIA}

Objetivou-se verificar a incidência de artigos publicados, na base de dados Pubmed, sobre resistência ao temefos em populações de Aedes aegypti. Para tanto, foram utilizados como descritores termos que garantissem maior abrangência e relação das consultas realizadas, conforme Figura 1.
Figura 1 - Termos descritores utilizados na busca por informações científicas para o desenvolvimento do trabalho.

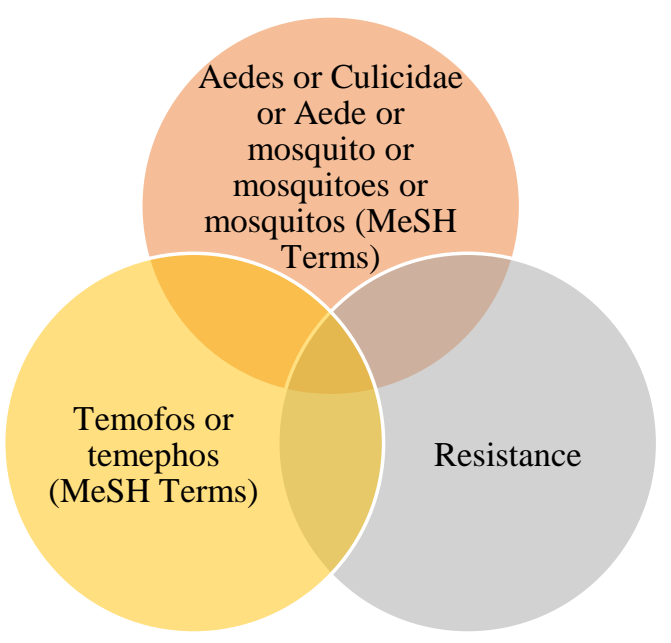

Fonte: Elaborado pelo autor.

Em seguida, foram examinados os resumos dos artigos publicados especificamente quanto ao tema em busca de alvos genéticos que mostre resistência inseticida do mosquito Aedes aegypti.

\section{GENES ENVOLVIDOS NA RESISTÊNCIA INSETICIDA EM AEDES AEGYPTI}

O mosquito Aedes aegypti é responsável pela transmissão do vírus da dengue. Devido à ausência de vacina disponível, o controle vetorial é o único método que pode ser utilizado na prevenção da infecção. Isso envolve o uso de inseticidas como armas vitais. Um deles é o temefos, larvicida organofosforado recomendado pela Organização Mundial de Saúde (OMS). 
Entretanto, devido ao uso exclusivo e intensivo, sem outras alternativas a serem utilizadas, casos de resistência tem sido relatados em diversas localidades do Brasil (STRODE et al, 2012), conforme Quadro 1.

Quadro 1 - Localidades do Brasil que registraram resistência de populações de $A$. aegypti ao temefos.

\section{Localidades}

Distrito Federal, Espírito Santo e Rio de Janeiro

\begin{tabular}{c}
\hline Campinas \\
\hline São Paulo \\
\hline Paraíba
\end{tabular}

Fonte - Quadro elaborado pelo próprio autor a partir de Beserra et al (2007).

Com base nestes dados, elaborou-se o Quadro 2 com o intuito de demonstrar a ocorrência de variação de alguns genes em mosquitos Aedes aegypti que resulta em resistência ao inseticida.

Quadro 2 - Genes envolvidos na resistência inseticida contra Aedes aegypti.

\begin{tabular}{ll}
\hline \multicolumn{1}{c}{ Artigo } & \multicolumn{1}{c}{ Genes de resistência } \\
\hline & Expressão de genes das \\
Poupardin et al & carboxilesterases \\
$(2014)$ & (CCEs): CCEae3A, e \\
& CCEae6C. \\
\hline
\end{tabular}

\begin{tabular}{ll}
\hline & Polimorfismo \\
& observado no gene da \\
& P450 CYP6N12 \\
Strode et al (2012) & associado com a \\
& expressão desse gene \\
& nas linhagens RecR e \\
& RecRev.
\end{tabular}

Fonte - Elaborado pelo autor.

Como exposto anteriormente, a resistência ao temefos em populações de Aedes aegypti tem aparecido em diversas localidades geográficas (BESERRA et al, 2007) e as causas ou os mecanismos podem ser os mais diversos, dentre eles o aumento na atividade metabólica de enzimas de detoxificação. Este processo é caracterizado pela superexpressão e/ou modificações estruturais nas moléculas enzimáticas, resultando no aumento da capacidade de detoxificar o inseticidas, conforme artigos expostos no Quadro 2. Por meio da elucidação do conjunto de todos os genes de mosquitos Aedes aegypti e consequente identificação de genes de detoxificação, podese perceber uma evolução do mosquito frente ação inseticida (STRODE et al, 2012).

\section{CONSIDERAÇÕES FINAIS}

De acordo com estudos realizados em várias localidades do Brasil, a resistência do mosquito Aedes aegypti frente ação inseticida 
está amplamente disseminada (BESERRA et al., 2007).

Tais dados confirma a hipótese de que a eficácia dos inseticidas utilizados contra o mosquito deve ser constantemente, profundamente e sistematicamente avaliada como medida de segurança à saúde pública, uma vez que a variação na população de Aedes aegypti deve-se à expressão de genes de resistência (STRODE et al, 2012).

\section{REFERÊNCIAS}

BESERRA, Eduardo B. et al. Resistance of Aedes aegypti (L.) (Diptera: Culicidae) populations to organophosphates temephos in the Paraíba State, Brazil. Neotropical

Entomology, v. 36, n. 2, p. 303-307, 2007.

CHEE DHANG, Chen. Temephos resistance in field aedes (Stegomyia) albopictus (Skuse) from Selangor, Malaysia. Tropical biomedicine, v. 30, 2013.

POUPARDIN, Rodolphe et al. Identification of carboxylesterase genes implicated in temephos resistance in the dengue vector Aedes aegypti. PLoS Negl Trop Dis, v. 8, n. 3, p. e2743, 2014.

RICARDO, Leyva Y. et al. [Effect of pyriproxyfen for the Aedes (S) aegypti control (Diptera: Culicidae) in strains with various degrees of temephos resistance]. Revista cubana de medicina tropical, v. 62, n. 3, p. 224-229, 2009.

STRODE, Clare et al. Expression profile of genes during resistance reversal in a temephos selected strain of the dengue vector, Aedes aegypti. PLoS One, v. 7, n. 8, p. e39439, 2012. 